\title{
Pembelajaran Flipped Classroom Terintegrasi Rumah Belajar Untuk Meningkatkan Ketrampilan Berfikir Tingkat Tinggi
}

\author{
Umi Rosidah \\ SMPN 2 Kepung \\ rosidahumi4@gmail.com
}

\section{Article History}

accepted 01/12/2020

approved 01/01/2021

published 01/03/2021

\begin{abstract}
Along with the extraordinary development of technology and information, there have been changes in various aspects of human life, both in work, socializing, playing and how to get knowledge. In order for students to survive in the 21st century, they need to be equipped with 21 st century skills competencies, one of which is the ability to think at a high level. This is very important because it will encourage students to always act actively and creatively at every opportunity and equip students to be able to solve various problems and challenges they will face in social society. To stimulate the increase in critical thinking skills in students, an appropriate learning model and media are needed. By integrating Flipped Classroom learning with Learning Houses, it is hoped that blended learning will occur which can improve students' ability to think critically so that it will be easier to understand the subject matter presented, which in turn will improve student learning outcomes and completeness. This study uses a Classroom Action research method, with the results of the study that learning Flipped Classroom can; (1) implemented effectively and efficiently (2) improving high-order thinking skills (3) learning integrated Flipped Classroom learning houses can improve student learning outcomes and completeness.
\end{abstract}

Keywords: flipped classroom, rumah belajar, Hight Order Thinking Skill

\begin{abstract}
Abstrak
Seiring dengan perkembangan teknologi dan informasi yang luar biasa, terjadi perubahan dalam berbagai sendi kehidupan manusia, baik dalam bekerja, bersosialisasi, bermain maupun cara memeperoleh pengetahuan. Agar peserta didik tetap bertahan di abad ke 21 ini, maka perlu dibekali kompetensi ketrampilan abad 21, salah satunya yaitu kemampuan berfikir tingkat tinggi. Hal ini sangat penting karena akan mendorong peserta didik agar selalu bertindak aktif dan kreatif disetiap kesempatan, serta membekali siswa agar dapat memecahkan berbagai masalah dan tantangan yang akan mereka hadapi dalam masyarakat sosial. Untuk menstimulasi meningkatnya kemampuan berfikir kritis pada peserta didik diperlukan sebuah Model dan media belajaran yang tepat. Dengan mengintegrasikan pembelajaran Flipped Classroom dengan Rumah Belajar, diharapkan akan terjadi blended learning yang dapat meningkatkan kemampuan peserta didik dalam berfikir kritis sehingga akan lebih mudah dalam memahami materi pelajaran yang disampaikan, yang pada akhirnya akan meningkatkan hasil dan ketuntasan belajar peserta didik. Penelitian ini menggunakan Metode penelitian Tindakan Kelas, dengan hasil penelitian adalah bahwa pembelajaran Flipped Classroom dapat; (1) dilaksanakan secara efektif dan efisien (2) meningkatkan kemampuan berfikir tingkat tinggi (3) pembelajaran Flipped Classroom terintegrasi rumah belajar dapat meningkatkan hasil dan ketuntasan belajar peserta didik.
\end{abstract}

Kata kunci: flipped classroom, rumah belajar, ketrampilan berfikir tingkat tinggi

Social, Humanities, and Education Studies (SHEs): Conference Series https://jurnal.uns.ac.id/shes

p-ISSN 2620-9284 e-ISSN 2620-9292 


\section{PENDAHULUAN}

Memasuki abad 21 kemajuan teknologi informasi dan komunikasi telah merubah gaya hidup manusia, menginfluensi berbagai sendi kehidupan baik dalam bekerja, bersosialisasi, bermain maupun cara memeperoleh pengetahuan. Untuk itu pendidik dan peserta didik dituntut memiliki kompetensi ketrampilan abad 21 agar tetap dapat bertahan. Kemampuan Abad 21 ditandai dengan adanya peningkatan secara signifikan terhadap perkembangann ilmu kognitif dan memiliki kemampuan digital Age literacy/ era literasi digital, inventive thinking/ berfikir inventif, dan effective communication/ berkomunikasi secara aktif. (Meitri, 2003)

Saat ini peserta didik telah menjadi generasai digital native yang dalam kesehariannya selalu menggunakan teknologi, dan pada akhirnya memiliki ekspektasi yang besar bahwa proses pembelajaran yang mereka lakukan akan memanfaatkan teknologi. Hal ini terjadi karena adanya shifting learning model di kalangan peserta didik, dari yang awalnya tradisional bergeser kearah digital, dari yang awalnya pembelajaran pasif di kelas, menjadi pembelajaran interaktif berbasis internet dan multimedia. Hal ini sebagai akibat semakin mudahnya akses terhadap informasi dan semakin berkembangnya dunia digital dan internet. Siswa tidak lagi merasa cukup hanya dengan belajar dari buku maupun dari keterangan gurunya, mereka akan dengan mudah mendapatkan informasi mengenai materi yang sedang mereka pelajari dari sumber lain yang menarik bagi mereka.

Seiring dengan perubahan tersebut tersebut, maka guru sebagai ujung tombak perubahan hendaknya juga mulai berubah dan berbenah. Paradigma pendidikan teacher centered tidak lagi sesuai dengan kondisi dan tantangan global yang sangat komplek. Sehingga di perlukan pengembangan kompetensi peserta didik yang mengarah kepada konsep berfikir abad 21 yang pada akhirnya benar-benar memiki ketrampilan abad 21 yang sangat diperlukan di masa yang akan datang agar dapat mencapai keberhasilan dan kesuksesan serta mampu memecahkan masalah mereka secara mandiri. Untuk itu sekolah perlu perlu menyiapkan standar baru agar siswa kelak memiliki kompetensi yang diperlukan pada abad ke-21. (Zubaidah, 2016).

Menurut Wagner (2009) mengidentifikasi ada 7 kecapakan hidup yang harus dimiliki oleh para pekerja, pelajar, dan individu sebagai warga negara agar dapat bertahan di abad ke-21, kecakapan tersebut antara lain adalah sebagai berikut: (1) kemampuan berfikir kritis dan problem solving; (2) kolaborasi dan kepemimpinan; (3) ketangkasan dan kemampuan beradaptasi; (4) inisiatif dan berjiwa kewirausahaan; (5) mampu berkomunikasi secara lisan dan tulis dengan efektif; (6) mampu mengakses dan menganalisis informasi, dan (7) memiliki rasa ingin tahu serta imajinatif.

Dari 7 kecakapan hidup abad ke-21, kemampuan berfikir kritis atau berfikir tingkat tinggi menjadi point pertama yang perlu menjadi perhatian kita. Hal ini karena dengan kemampuan berfikir tingkat tinggi akan mendorong seseorang dalam hal ini adalah peserta didik agar selalu bertindak aktif dan kreatif disetiap kesempatan, serta membekali siswa agar dapat memecahkan berbagai masalah dan tantangan yang akan mereka hadapi dalam masyarakat sosial. (Afandi dan Sajidan, 2018). Maka menjadi kewajiban bagi sekolah untuk dapat memberdayakan berbagai ketrampilan berfikir dalam pembelajaran sesuai dengan kharakteristik pembelajaran pada masingmasing jenjang pendidikan.

Menurut para Ahli kemampuan berfikir tingkat ditandai dengan aktifitas berfikir yang kompleks dan mendalam pada saat memahami sebuah materi, dalam membuat kesimpulan, membangun konsep, menganalisis, dan membangun hubungan antar kompetensi yang melibatkan aktivitas berfikir yang paling dasar yang penting dalam proses berfikir tingkat tinggi selanjutnya. Karena untuk mencapai proses berfikir tingkat inggi, juga tetap diperlukan ketrampilan berfikir tingkat rendah yaitu mengingat (remembering), memahami (understanding), dan menerapkan (applying) yang akan menunjung sesorang dalam mencapai ketrampilan berfikir tingkat tinggi yaitu 
menganalisis (analysing), mengevaluasi (evaluating), dan mencipta (creating). (Ariyana, dkk, 2018)

Kemampuan berfikir tingkat tinggi dalam taksonomi Bloom menjadi puncak pencapaian seseorang dalam proses berfikir. Pemikiran tingkat tinggi dipahami sebagai kemampuana peserta didik dalam menghubungkan pembelajaran dengan elemen lain diluar kemampuan peserta didik untuk mengasosiasikan dengan pemahan yang telah dia miliki sebelumnya (Brookhart, 2010). Jadi dalam ketrampilan High Order Thinking Skill terdapat proses berfikir secara kritis dalam menggunakan seluruh pengetahuan dan ketrampilan yang dimilikinya untuk melakukan problem solving, mengambil keputusan, menganalisis data dan informasi, serta menarik kesimpulan untuk menghasilkan informasi atau kesimpulan seperti yang diharapkan.

Untuk menstimulasi meningkatnya kemampuan berfikir kritis pada peserta didik diperlukan sebuah Model dan media belajaran yang tepat. Dengan mengintegrasikan pembelajaran Flipped Classroom dengan Rumah Belajar, diharapkan akan terjadi blended learning yang dapat meningkatkan kemampuan peserta didik dalam berfikir kritis sehingga akan lebih mudah dalam memahami materi pelajaran yang disampaikan, yang pada akhirnya akan meningkatkan hasil dan ketuntasan belajar peserta didik.

\section{METODE PENELITIAN}

Penelitian yang dilakukan merupakan jenis Penelitian Tindakan Kelas. Penelitian ini mengambil tempat di kelas VII E UPTD SMP Negeri 2 Kepung dengan alamat Jl. Kandangan K.M 7 Ds. Keling Kec. Kepung Kab. Kediri, pada matapelajaran PAI di semester II tahun pelajaran 2018/2019. Dengan jumlah peserta didik perempuan 14 dan laki-laki berjumlah 18 orang.

Penelitian ini dilaksanakan dalam periode waktu 2 kali siklus tindakan, dengan rincian tiap minggu alokasi jam pelajarannya 3X40'. Setiap siklus tindakan memerlukan waktu $2 \mathrm{X}$ pertemuan sehingga waktu yang diperlukan untuk 2 kali siklus adalah 12 Jam atau dalam1 bulan. Dalam prosedur pengumpulan data penulis menggunakan beberapa metode pengumpulan data yaitu: yang pertama, Jurnal pengamatan pembelajaran yaitu jurnal pengamatan belajar diisi oleh kolaborator dan peneliti, dilaksanakan untuk memantau setiap aktivitas peserta didik selama proses pembelajaran menggunakan metode pembelajaran Flipped Classroom terintegrasi Rumah Belajar, dan yang ke dua dokumentasi kegiatan pembelajaran berupa Video, foto-foto selama proses pembelajaran dan hasil tes pada saat siklus 1 dan siklus 2 dilaksanakan .

Untuk Analisis data dalam penelitian ini menggunakan teknik analisis deskriptif kualitatif - kuantitatif. Analisis data secara kualitatif digunakan untuk menganalisis data kualitatif, seperti hasil observasi dan studi dokumentasi. Data kualitatif yaitu data yang berupa informasi berbentuk kalimat yang memberi gambaran tentang aktivitas siswa selama proses pembelajaran, tingkat pemahaman siswa terhadap materi yang disampaikan dan kemampuan siswa dalam menganalisis, mengevaluasi dan mencipta kan hal-hal baru sesuai dengan kriteria pembelajaran HOTS. Analisis kualitatif terhadap data dilakukan dengan tahap-tahap: menyeleksi, menyederhanakan, mengklasifikasi, memfokuskan, mengorga-nisasi (mengaitkan gejala secara sistematis dan logis: reduksi data (memilah data penting, relevan, dan bermakna dari data yang tidak berguna), Sedangkan analisis data kuantitatif digunakan untuk menganalisis data-data yang berupa angka-angka, yang disjikan secara deskriptif (narasi, visual gambar, tabel) dengan alur sajian yang sistematis dan logis, dan penyimpulan dari hasil yg disajikan. (Miles, M.B, Huberman, 1992). 


\section{HASIL DAN PEMBAHASAN \\ Pembelajaran Flipped classroom terintegrasi Rumah Belajar}

Menurut pioner Flipped classroom Bergmann \& Sams (2013) Secara sederhana Flipped Classroom diartikan sebagai "what is done at school done at home, homework done at home completed in class". Jika dimaknai flipped classroom artinya kelas terbalik dengan cara membalik siklus pemerolehan penerapan materi dalam pembelajaran. Yaitu dengan cara memberikan pengetahuan yang diperlukan oleh peserta didik sebelum kelas/ di rumah kemudian guru membimbing siswa aktif dan interaktif mengklarifikasi dan menerapkan pengetahuan yang telah didapatnya itu selama di kelas. Dalam hal ini Bergman \& Sams menggunakan video pembelajaran serta kelas online untuk memberikan pembimbingan dan arahan selama peserta didik belajar di rumah. Meskipun menggunakan video untuk pembelajaran di rumah sebagai alternatif penyampaian materi, akan tetapi Flipped Classroom bukanlah pembelajaran kelas Online sepenuhny, dan bukan juga menggunakan Video sebagai pengganti guru secara total, bukan pembelajaran yang tanpa perencanaan, bukan juga berarti pembelajaran secara mandiri oleh peserta didik, akan tetapi poin penting yang harus dilakukan pada pembelajaran Flipped Classroom adalah adanya interaksi aktif antara guru dan peserta didik menjadi lebih meningkat saya mereka bertemu di kelas. (Milman, 2012).

Desain pembelajaran yang di lakukan pada penelitian ini adalah terdiri atas tiga komponen, yaitu sebelum di kelas, selama di kelas, dan sesudah di kelas. Hal ini sesuai dengan skema pembelajaran Flipped Classroom berikut ini:

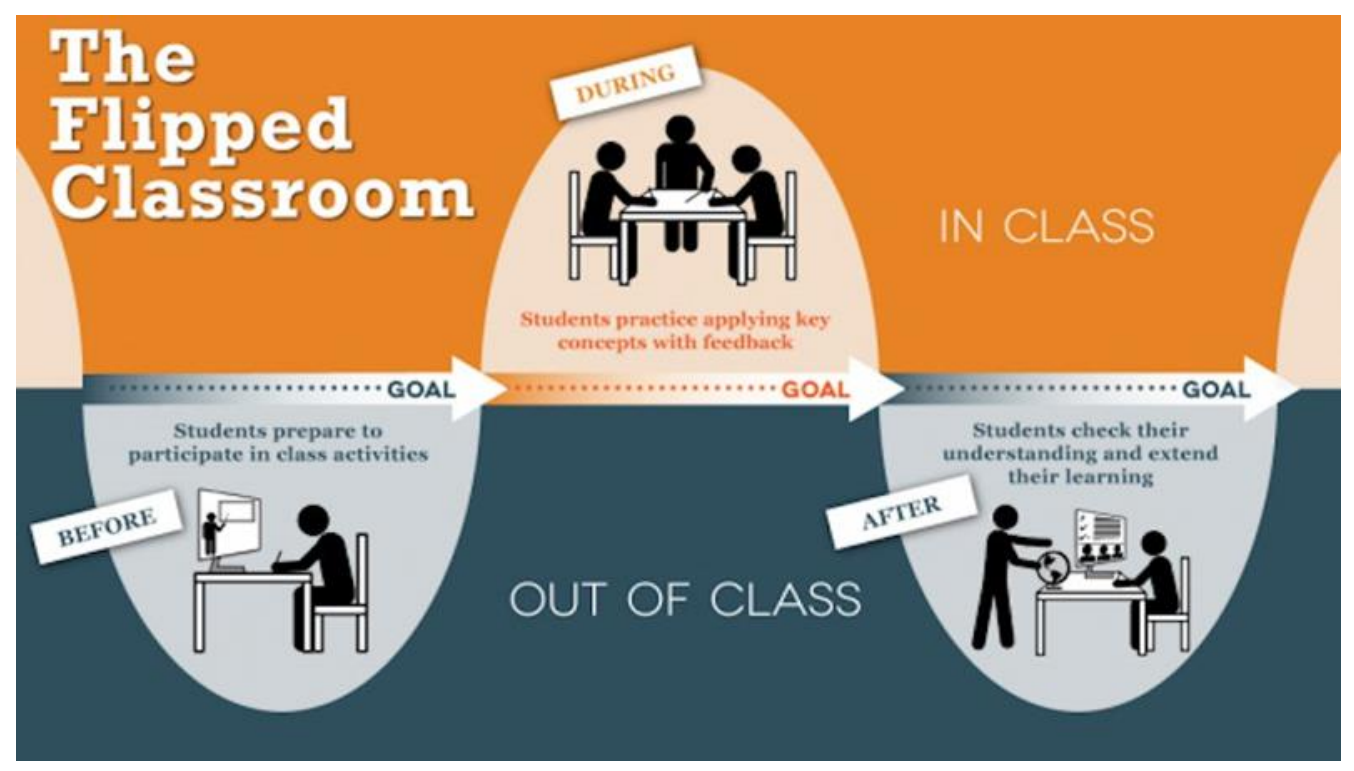

Gambar 1. https://facultyinnovate.utexas.edu/flipped-classroom

Dalam pelaksanaan Penelitian Tindakan Kelas ini masing-masing siklusnya melalui tahapan pembelajaran seperti di atas dengan skema sebagai berikut: 

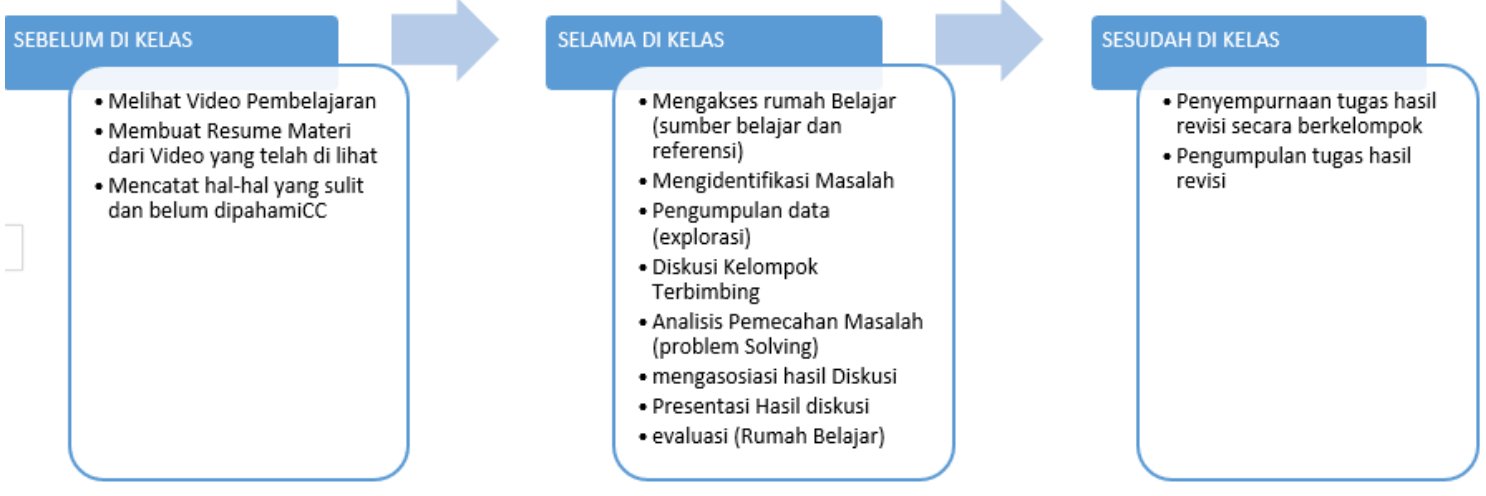

Gambar 2. Skema Pelaksanaan PTK

Untuk video pembelajaran yang digunakan pada pembelajaran Flipped Classroom sebelum di kelas pada siklus 2 , adalah video pembelajaran yang dibuat sendiri oleh peneliti. Hal ini merupakan salah satu hasil evaluasi dari kolaborator yang menemukan bahwa pada siklus satu, masih ada 31\% siswa yang tidak melihat video pembelajaran yang telah ditentukan. Untuk meningkatkan minat peserta didik dalam mempelajari materi ketika di rumah, maka penulis membuat video tutorial pembelajaran yang di desain sedemikian rupa menggunakan software Camtasia. Selain berupa penjelasan materi, video pembelajaran tersebut juga ditambahkan animasi, musik pendukung dan teks animatif (videoscribe) agar lebih menarik dan mudah untuk dipahami. Berikut ini adalah contoh video pembelajaran yang telah penulis buat dan telah masuk ke chanel Rumah Belajar:

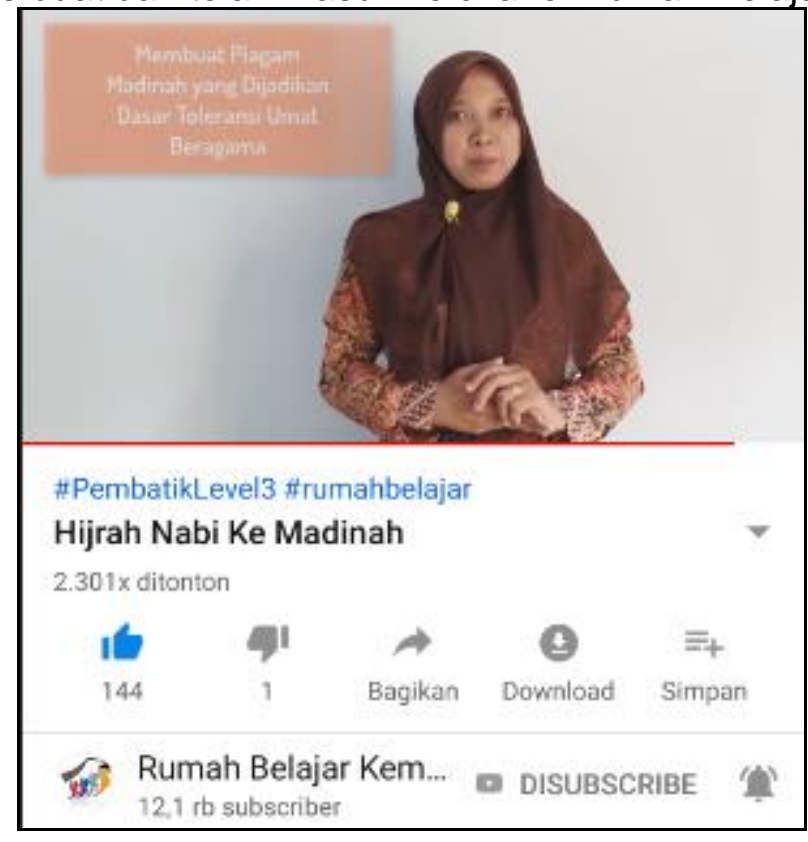

\section{Gambar 3. Video pembelajaran mengenai materi Hujrah Nabi Ke Madinah}

Kemudian mengapa kita menggunakan Rumah Belajar? Karena Rumah Belajar adalah layanan pembelajaran yang dikembangkan oleh Kementerian Pendidikan dan Kebudayaan melalui Pusat Teknologi Informasi dan Komunikasi Pendidikan dan Kebudayaan (PUSTEKKOM) yang di dalamnya tersedia berbagai macam sumber belajar yang variatif, dan dalam pengembangan sumber belajarnya dilakukan oleh 
tenaga yang terlatih dan selalau didasarkan pada referensi sehingga kualitas bahan pembelajaran yang ada belajar Rumah Belajar terjamin kualitasnya. Selain itu di dalam rumah belajar banyak sekali fitur-fitur yang tersedia untuk menunjang pebelajaran yang bermutu. Fitur-fitur di dalam rumah belajar antara lain; sumber belajar untuk seluruh mapel, mulai dari SD hingga tingkt SMA/ SMK. Kemudian ada juga buku sekolah elektronik, bank soal, labolatorium maya, peta budaya, wahana jelajah angkasa, kelas maya, dan pengembangan keprofesian berkelanjutan (diklat online). Serta masih ada juga fitur pendukung yaitu karya guru, karya komunitas dan karya bahasa dan sastra.

Dalam aplikasiannya rumah belajar menjadi sumber utama ketika pembelajaran tahap ke dua Flipped Classroom, yaitu pembelajaran selama di kelas. Setiap proses pembelajaran di kelas akan melibatkan peserta didik secara aktif dan kreatif jika ditunjang dengan sumber belajar yang lengkap dan menarik. Peserta didik tentu akan mengalami kesulitan mengembangkan pemikiran mereka lebih jauh lagi, mereka juga akan kesulitan dalam menganalisis masalah serta berfikir kreatif tanpa ada referensi yang memadai. Dengan mengintegrasikan pengetahuan yang telah mereka terima sebelumnya yaitu dari melihat video pembelajaran di rumah, dengan materi yang ada di rumah belajar maka diharapkan akan semakin meningkatkan kemampuan mereka dalam berfikir kritis, efektif dan kreatif.

\section{Pembelajaran Flipped Classroom terintegasi Rumah Belajar Untuk Meningkatkan Ketrampilan Berfikir Tingkat Tinggi}

Menurut Brookhart (2010) dalam kegiatan pembelajaran yang berorietasi pada proses berfikir tingkat tinggi, akan menstimulasi 3 aspek berfikir tingkat tinggi yaitu: ketrampilan berfikir tingkat tinggi sebagai transfer of Knowledge, ketrampilan berfikir tingkat tinggi sebagai critical and creative thinking, dan ketrampilan berfikir tingkat tinggi sebagai problem solving

Ketrampilan berfikir tingkat tinggi sebagai transfer of Knowledge bertujuan untuk membekali peserta didik agar dapat melakukan transfer pengetahuan dan ketrampilan yang mereka terima selama pembelajaran menjadi sebuah konteks baru. baru yang di maksud bukanlah sesuatu yang secara universal merupakan sesuatu yang baru akan tetapi sebuah konteks yang tidak terfikir sebelumnya oleh peserta didik. Untuk dapat mengembangkan ketrampilan berfikir tingkat tinggi sebagai transfer of Knowledge, diperlukan sebuah persiapan kemampuan kognitif tingkat rendah yaitu mengingat (remembering), memahami (understanding), menerapkan (Applaying). Jika proses berfikir tingkat rendah Low Order Thingking Skill (LOTS) ini sudah terpenuhi maka kita dapat melanjutkan ke level berfikir yang selanjutnya yaitu High Order Thingking Sklill (HOTS) yaitu menganalisis (analysing), mengevaluasi (evaluating), dan mencipta (creating). Akan tetapi sering kali pembelajaran yang dilakukan di kelas tradisional hanya sampai pada proses mengingat dan memahami saja, hal ini disebabkan tidak adanya persiapan dari peserta didik sebelum memasuki kelas, maka waktu di kelas akan habis untuk memberikan materi. Untuk itu pembelajaran Flipped Classrom dapat menjadi solusi atas situasi ini. Karena setiap peserta didik memiliki gaya mengajar yang berbeda, dan kemampuan menerima pengetahuan yang juga berbeda, dengan menggunakan video pembelajaran sebelum masuk kelas, akan menarik perhatian mereka untuk belajar, selain itu penyelesain materi pelajaran dapat mereka sesuaikan dengan kemampan mereka sendiri. Jika mereka merasa kurang memahami materi yang sedang di pelajari mereka dapat mengulanginya sampai mereka memahi materi tersebut

Ketrampilan berfikir tingkat tinggi sebagai critical and creative thinking menurut Brookhart (2010) adalah kemampuan peserta didik dalam menerapkan penilaian yang bijaksana dan menghasilkan kritik yang beralasan sehingga mereka dapat mengambil keputusan yang sesui dengan kondisi dan situasi yang sedang terjadi. Dengan 
membalik cara pemeroleh materi, akan memberikan kesempatan yang lebih luas bagi guru dan peserta didik untuk saling berinteraksi, baik antara guru dan peserta didik maupun antara peserta didik degan peserta didik yang lain. Dengan adanya interaksi yang lebih luas diharapkan peserta didik lebih banyak memperoleh feed back selama proses pembelajaran, seingga kemampuan berfikir kritis dan kreatif dapat lebih di tingktkan.dan tra

Ketrampilan berfikir tingkat tinggi sebagai problem solving menurut Brookhart (2010) adalah kemapuan peserta didik di dalam mengidentifikasi dan memecahkan masalah yang sedang di hadapinya, baik permasalahan yang di setting sedemikian rupa maupun masalah baru yang mereka temukan sendiri selama proses pembelajaran kemudian menciptakan sesuatu yang baru sebagai solusinya. Dalam pembelajaran Flipped Classroom Ketrampilan berfikir tingkat tinggi sebagai problem solving ini dapat kita kembangkan pada saat pembelajaran Flipped Classrom selama di kelas. dengan modal awal pengetahuan yang sudah dimiliki peserta sebelumnya kita dapat merancang pembelajaran di kelas yang lebih variatif, misalnya kegiatan diskusi terbimbing dalam mengidentifikasi masalah, mengumpulkan data, menganalisis masalah dengan menyediakan sumber belajar interaktif atau multimedia yaitu rumah belajar sebagai stimulus agar peserta didik dapat mengembangkan proses berfikir kritis dan memahami materi dengan lebih mendalam. Sehingga pengetahuan yang mereka terima tidak hanya dari guru saja akan tetapi juga dari sumber lain, sehingga kegiatan problem solving ini dapat dilakukan secara maksimal.

\section{Hasil Belajar Peserta Didik Pada Pembelajaran Flipped Classroom Terintegrasi Rumah Belajar}

Setelah melaksanakan pembelajaran Flipped Classrom terintegrasi Rumah Belajar menunjukkan bahwa hasil belajar peserta didik mengalami peningkatan yang cukup signifikan dan untuk lebih jelasnya dapat dilihat pada tabel di bawah ini:

Tabel 1. Tabel Analisi Hasil Ulangan Siklus 1 dan Siklus 2

\begin{tabular}{|c|c|c|c|c|}
\hline Aspek yang diukur & Siklus I & Presentase & Siklus II & Presentase \\
\hline Rata-rata kelas & 66,2 & & 80,2 & 80,2 \\
\hline $\begin{array}{l}\text { Ketuntasan Indiviual } \\
\text { dengan kualifikasi amat } \\
\text { baik }\end{array}$ & 1 Orang & $(4 \%)$ & 7 Orang & $(24 \%)$ \\
\hline $\begin{array}{l}\text { Ketuntasan Indiviual } \\
\text { dengan kualifikasi baik }\end{array}$ & 4 Orang & $(14 \%)$ & 14 Orang & $(48 \%)$ \\
\hline $\begin{array}{lr}\text { Ketuntasan } & \text { Indiviual } \\
\text { dengan } & \text { kualifikasi } \\
\text { Cukup baik } & \end{array}$ & 9 Orang & $(31 \%)$ & 3 Orang & $(11 \%)$ \\
\hline $\begin{array}{lr}\text { Ketuntasan } & \text { Indiviual } \\
\text { dengan } & \text { kualifikasi } \\
\text { Kurang } & \end{array}$ & 15 Orang & $(51 \%)$ & 5 Orang & $(17 \%)$ \\
\hline $\begin{array}{l}\text { Jumlah Siswa Tuntas } \\
\text { Jumlah Siswa yang } \\
\text { tidak Tuntas }\end{array}$ & $\begin{array}{l}14 \text { Orang } \\
15 \text { Orang }\end{array}$ & $\begin{array}{l}49 \% \\
51 \%\end{array}$ & $\begin{array}{c}24 \text { Orang } \\
5 \text { Orang }\end{array}$ & $\begin{array}{l}83 \% \\
17 \%\end{array}$ \\
\hline
\end{tabular}

Dari tabel analisis hasil ulangan pada siklus 1 dan siklus 2 di atas dapat diketahui mengenai peningkatan hasil belajar yang dicapai oleh peserta didik di kels 7E. klasifikasi nilai pada tabel di atas berdasarkan pedoman penilai yang di susun oleh Tim Pengembang Kurikulum di SMPN 2 Kepung. Untuk KKM (kriteria ketuntasan 
minimum) yang digunakan di SMPN 2 Kepung adalah 68. Berikut ini adalah Predikat dan rentang nilai yang di jadikan acuan dalam penilaian di SMPN 2 Kepung:

$$
\begin{array}{ll}
A=90-100 & \text { (Amat Baik) } \\
B=79-89 & \text { (Baik) } \\
C=68-78 & \text { (Cukup) } \\
D=<68 & \text { (Kurang) }
\end{array}
$$

Berdasarkan tabel di atas pada siklus 1 hanya $49 \%$ saja peserta didik yang tuntas, kemudian pada siklus 2 jumlah siswa yang tuntas sebesar $83 \%$. Berdasarkan ketentuan penilaian yang ada di SMPN 2 Kepung pembelajaran dikatakan tuntas secara klasikal jika $75 \%$ dari peserta didik di kelas tersebut mencapai nilai KKM. Karena pada siklus 2 peserta didik yang tuntas sebesar $83 \%$ maka secara klasikal pembelajaran di sklus 2 telah tuntas, meskipun masih ada beberapa siswa yang belum tuntas. Maka bagi siswa yang belum tuntas dapat mengikuti remidi agar dapat mencapai nilai KKM yang telah ditentukan yaitu 68. Untuk mengetahui perbandingan tingkat ketuntasan peserta didik pada siklus 1 dan 2 dapat kita lihat pada grafik berikut ini:

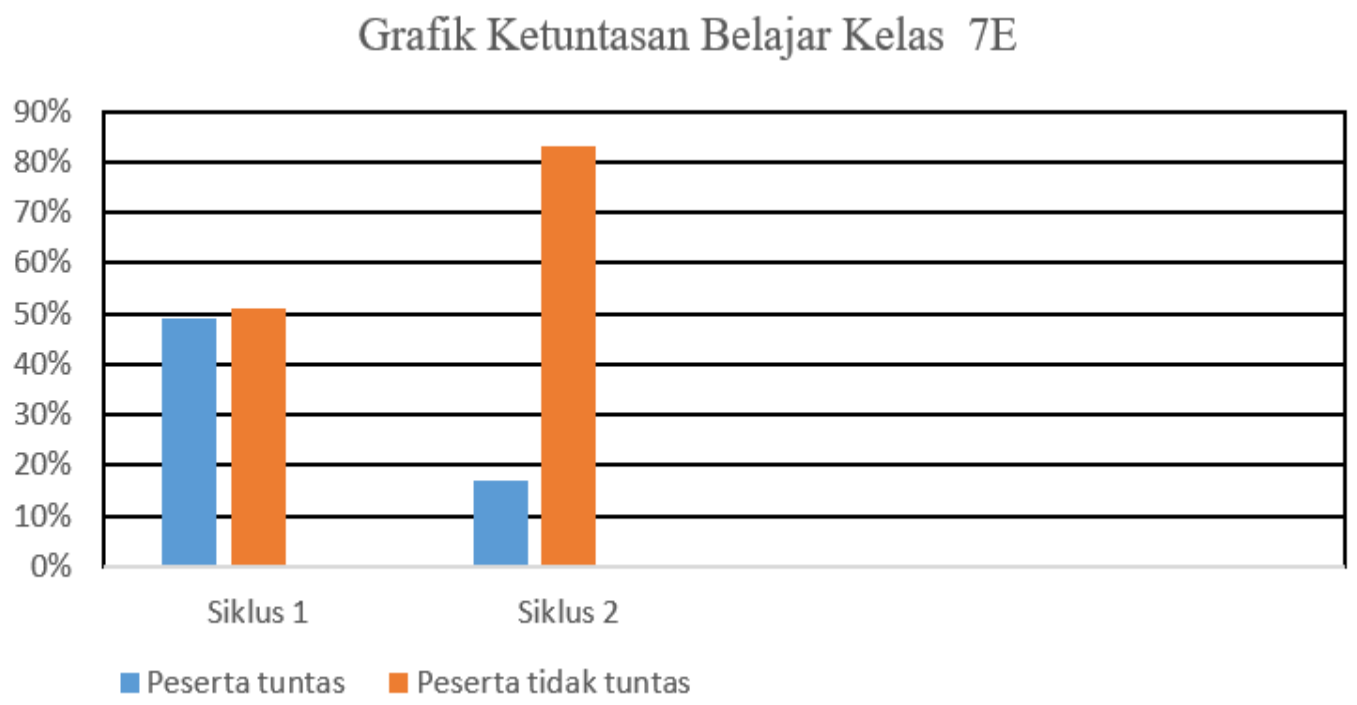

\section{Gambar 5. Perbandingan Presentase Peserta Didik yang Tuntas dan Tidak Tutas Pada Siklus 1 dan 2}

\section{SIMPULAN}

Dari serangkaian penilitian tindakan kelas yang dilakukan mulai dari perencanaan, pelaksanaan, observasi dan refleksi yang telah dilakukan, serta hasil analisis data-data yang ada maka dapat ditarik kesimpulan bahwa proses pembelajaran Flipped classroom terintegrasi Rumah Belajar dapat dilaksanakan secara efektif karena dapat meningkatkan ketrampilan berfikir tingkat tinggi. Hal ini disebabkan karena dengan cara membalik siklus pemerolehan materi bagi peserta didik akan memiliki kesempatan untuk mengembangakan ketrampilan berfikir tingkat tinggi peserta didik di dalam kelas karena sebelumnya mereka telah memiliki pengetahuan yang telah mereka pelajari sebelumnya di rumah. Sehigga kegiatan pembelajaran dapat lebih diarahkan untuk kegaitan analisis, evaluasi dan mengkreaasi/ mencipta. Dengan pembelajaran Flipped Classrom terintegrasi rumah belajar juga dapat meningkatan hasil belajar dan ketuntasan belajar peserta didik yaitu pada siklus I adalah 66, 28 maka pada silklus II 
menjadi 80, 55 dan Jika pada siklus 1 peserta didik yang tuntas hanya $49 \%$ maka pada siklus 2 meningkat menjadi 83\%. Agar pembelajaran Flipped Classroom ini berjalan lebih baik lagi maka disarankan untuk mengkombinasikannya dengan model pembelajaran LMS (learning Manajement System) karena interaksi antara guru dan peserta didik akan lebih intensif karena sudah dibangun sejak sebelum masuk kelas dan kemampuan berfikir tingkat tinggi peserta didik juga akan semakin meningkat jika semakin banyak feed back yang diterima oleh peseta didik, oleh karena itu keterkaitan antara pembelajaran sebelum, selama dan sesudah dikelas harus benar-benar di optimalkan..

\section{DAFTAR PUSTAKA}

Afandi \& Sajidan. (2018). Pemberdayaan Ketrampilan Berfikir Tingkat Tinggi Ditinjau dari Aspek Epigenetik dan Implikasinya dalam Pendidikan. https://www.researchgate.net/publication/32821198, diunduh di Kediri, 7 September 2019

Ariyana, Yoki. (2018). Buku Pegangan Pembelajaran Berorientasi Pada Ketrampilan Berfikir Tingkat Tinggi. Direktorat Jendral Guru dan Tenaga Kependidikan Kementrian Pendidikan dan Kebudayaan.

Brookhart. Susan. M. (2010). How to Assess Higher-Order Thinking Skill in Your Class Room. (Electronic Resource). http://mpi.uinsgd.ac.id/wpcontent/uploads/2018/07/Susan-M.-Brookhart-How-to-Assess-Higher-Order-

Thinking-Skills-in-Your-Classroom-Association-for-Supervision-CurriculumDevelopment-2010.pdf, diunduh di Kediri, 8 Sepetember 2019

Metiri. (2003). EnGauge 21st Century Skiil: Helping Students Thrive in digital Age. www.ncrel.org/engauge, diunduh di Kediri, 7 September 2019

Miles, M.B. \& Huberman, A.M. (1992) Analisis data kualitatif : Buku sumber tentang metode-metode baru, Terjemahan Tjetjep Rohendi Rohidi. Beverly Hills CA : Sage Publications, Inc.

Milman, Natalie. B. (2012) The Flipped Classroom Strategy: What Is It and How Can It Best Be Used. https://www.academia.edu/22761397/The_Flipped_Classroom_Strategy_What_I S_It_and_How_Can_It_Best_Be_Used, diunduh di Kediri, 7 September 2019

Wagner.T. (2009). The Global Achievement Gap (Electronic Resource). https://archive.org/details/globalachievemen00wagn/page/n9, diunduh di Kediri, 7 september 2019

Zubaidah, Siti. (2016). Ketrampilan Abad ke-21: Ketrampilan yang Diajarkan Melalui Pembelajaran. https://www.researchgate.net/publication/318013627. Diunduh di Kediri, 7 September 2019 